UDC 373.5.016

DOI https://doi.org/10.31470/2415-3729-2021-13-191-203

\title{
Critical Thinking of Students: Essence, Structure, Conditions of Development
}

\section{Anastasiia Ostapenko}

Postgraduate,

H.S. Skovoroda Kharkiv National Pedagogical University,

$\triangle$ 2, Valentynivska Str., Kharkiv, Ukraine, 61022

E-mail: nastya.tripolko.98@gmail.com

ORCID:https://orcid.org/0000-0002-3973-8753

Date of receipt of the article: April 17, 2021

Article accepted for publication: June 02, 2021

\section{Критичне мислення учнів: суть, структура, умови розвитку}

\author{
Анастасія Віталіївна Остапенко \\ аспірант, \\ Харківський національний педагогічний університет імені Г.С. \\ Сковороди \\ $\triangle$ вул. Валентинівська 2, Харків, Україна. \\ Дата надходження статті: 17 квітня $2021 \mathrm{p}$. \\ Стаття прийнята до друку: 02 червня 2021 p.
}

\section{Absract}

The article analyzes and defines the essence of the concept of «critical thinking», presents the structure of critical thinking. The purpose of the article is to reveal the essence of the concept of «critical thinking», to determine its structure and to characterize the conditions of its effective development on the basis of the conducted analysis of the scientific literature. The following methods were used in the study: analysis and interpretation of domestic and foreign philosophical, normative, psychological, pedagogical and methodological literature; analysis and generalization of advanced domestic, foreign and personal pedagogical experience on the research problem. The results. On the basis of the considered position of the theory of critical thinking development according to S. Terno and regularities on which this 
technique is based, the procedures which belong to the operating block of critical thinking are defined. The essence of the concept of «students' critical thinking» is interpreted as a system of judgments that is used to analyze things and events with the formulation of sound conclusions and allows students to make sound judgments and interpretations, as well as correctly apply conclusions to situations and problems. The peculiarities of the development of students' critical thinking include the following: the consistent pattern of dynamics, according to which the number of all subsequent changes depends on the number of changes at the previous stage; the regularity of personality development in the educational process; the regularity of educational process management; the stimulation regularity; the regularity of unity of sensory, logical and practice in the educational process; the regularity of unity of external (pedagogical) and internal (cognitive) activities; the regularity of the educational process conditionality. It is proved that the structure of students' critical thinking consists of three components: motivational, activity, reflexive-evaluative. The author developed a model for the development of students' critical thinking, the tasks of which are: mastering by students the knowledge of logical, problem, creative thinking; teaching students the basic logical concepts (reflection - denial - criticism - criticism - self-criticism - argumentation - proof - refutation - evaluation - self-evaluation - evaluative judgment); forming the students' ability to build critical reasoning; teaching students to identify logical errors of critical assessment of the phenomenon, behavior. Conclusions. The results of the study showed that an effective means of managing the process of forming students' critical thinking is the use of techniques and methods for solving problems, and that different forms and methods of teaching are used depending on the content of teaching, teaching aids, the students' individual characteristics of the study level, and the level of teachers' readiness to the development of critical thinking of students.

Key words: students, educational process, development, critical thinking, conditions, structure, regularities.

\section{References}

1. Bielkina, O.V. (2000). Problema formuvannia krytychnoho myslennia $\mathrm{v}$ uchniv pochatkovykh klasiv [The problem of forming critical thinking in primary school students]. Problemy pedahohichnykh 
tekhnolohii-Problems of pedagogical technologies, 2000, 1, 50-57 [in Ukraine].

2. Bohdanova, O. (2006). Vykorystannia metodyk rozvytku krytychnoho myslennia na urokakh istorii [The use of methods for the development of critical thinking in history lessons]. Istoriia Ukrainy - History of Ukraine, 2006, 9 (457), 6-12 [in Ukraine].

3. Denysevych, O. O. (2011). Rol krytychnoho myslennia v osvitnii reformi vyshchoi shkoly epokhy informatsiinoho suspilstva [The role of critical thinking in the educational reform of higher education in the information society]. Istoriia Ukrainy - Philosophy. Culturology, 2011, 1,155-159 [in Ukraine].

4. Zhernovnykova, O. A. (2015). Dydaktychna pidhotovka maibutnikh uchyteliv matematyky do proektuvannia navchalnoi diialnosti starshoklasnykiv: teoretychnyi ta metodychnyi aspekty [Didactic preparation of future teachers of mathematics to design of educational activity of senior pupils: theoretical and methodical aspects]. Kharkiv : Vydavets Ivanchenko I.S. [in Ukraine].

5. Kalashnikova, L. M. \& Zhernovnykova, O. A. (2016). Pedahohika vyshchoi shkoly $\mathrm{v}$ skhemakh i tablytsiakh [Pedagogy of high school in schemes and tables] Kharkiv : KhNPU imeni H. S. Skovorody [in Ukraine].

6. Kyienko-Romaniuk, L. A. (2007). Rozvytok krytychnoho myslennia studentskoi molodi yak zahalnopedahohichna problema [Development of critical thinking of student youth as a general pedagogical problem]. Candidate's thesis. Kyiv: Insytut vyshchoi osvity NAPN Ukrainy [in Ukraine].

7. Kovalenko, O.A. \& Zhernovnykova, O.A. (2021). Vykhovannia intelektualnoi elity natsii: zarubizhnyi ta vitchyznianyi dosvid [Education of the nation's intellectual elite: foreign and domestic experience]. Ridna shkola - Native school, 3, 25-29 [in Ukraine].

8. Korinko, L. M. (2010). Rol krytychnoho myslennia u formuvanni uchnivskykh kompetentsii [The role of critical thinking in the formation of students' competencies]. Kharkiv : Vyd. hrupa «Osnova» [in Ukraine].

9. Makarenko, V. M. (2007). Urok matematyky v suchasnykh tekhnolohiiakh: teoriia i praktyka. Rozvytok krytychnoho myslennia. Modulne navchannia [Mathematics lesson in modern technologies: 
theory and practice. Development of critical thinking. Modular learning]. Kharkiv: Osnova [in Ukraine].

10. Maksymenko, S. D. (2000). Myslennia. Zahalna psykholohiia [Thinking. General psychology]. Kyiv : Forum [in Ukraine].

11. Marchenko, O. H. (2007). Formuvannia krytychnoho myslennia shkoliariv [Formation of critical thinking of schoolchildren]. Kharkiv : Osnova [in Ukraine].

12. Matviiets, S. (2009). Rozvytok krytychnoho myslennia v konteksti kompetentnisno oriientovanoho navchannia [Development of critical thinking in the context of competency-based learning]. Istoriia Ukrainy - History of Ukraine, 10 (602), 10-13 [in Ukraine].

13. Terno, S.O. (2012). Metodyka rozvytku krytychnoho myslennia shkoliariv u protsesi navchannia istorii [Methods of developing critical thinking of students in the process of teaching history]. Zaporizhzhia: Zaporizkyi natsionalnyi universytet [in Ukraine].

14. Daud, N. M. (2004). Developing Critical Thinking Skills in Computer-Aided Extended Reading Classes. British Journal of Educational Technology, 35 (4), 477-488.

15. Stancato, F. A. (2000). Tenure, Academic Freedom and the Teaching of Critical Thinking. College Student Journal. RL: http:// findarticles.com/p/articles/mi_m0FCR/is_3_34/ai_66760558/.

\section{Вступ}

Із розвитком інформаційних технологій постають нові проблеми та цілі розвитку освіти в Україні, зокрема проблема розвитку критичного мислення учнів. Напрацювання вчених та педагогів практиків надають підстави стверджувати, що сучасним дітям важко мислити критично, сприймати відому їм інформацію в новому контексті, висувати припущення, критично оцінювати інформацію та розв'язувати проблемні ситуації. Тож у Стандарті базової середньої освіти (2021) передбачено розвиток відповідних умінь та навичок.

Критичне мислення - це необхідне вміння і важливий ресурс сучасної людини. Критичне мислення базується на законах логіки та на розумінні психологічних процесів нашої свідомості, а тому важливо забезпечити з боку вчителя комплексний та грунтовний підхід до навчання. Потрібно забезпечити володіння стратегіями критич- 
ного мислення та використання провідних методик розвитку критичного мислення учнів вчителем у своїй педагогічній діяльності та повсякденному житті.

Проведений аналіз наукової літератури надає підстави стверджувати, що українські та зарубіжні вчені мають напрацювання за такими напрямами дослідження: проблема формування та розвитку критичного мислення в учнів та студентів (Бєлкіна, 2000; КиєнкоРоманюк, 2007; Макаренко, 2007; Марченко, 2007; Матвієць, 2009); використання методик розвитку критичного мислення учнів під час уроків (Богданова, 2006; Терно, 2012; Stancato, 2000); роль критичного мислення в сучасній системі освіти (Денисевич, 2011; Корінько, 2010; Daud, 2004); підготовка вчителя до розвитку критичного мислення учнів (Жерновникова, 2015; Коваленко, 2021); психологопедагогічне підгрунтя розвитку критичного мислення особистості (Максименко, 2000).

Разом $з$ тим, актуальність означеної проблеми постійно зростає, оскільки нерозв'язаними залишаються питання розвитку та формування критичного мислення учнів в умовах нової української школи.

Мета статті - на основі проведеного аналізу наукової літератури розкрити суть поняття «критичне мислення», визначити його структуру та схарактеризувати умови його ефективного розвитку.

\section{Матеріал і методи дослідження}

При дослідженні були використані такі методи: аналіз та інтерпретація вітчизняної і зарубіжної філософської, нормативної, психолого-педагогічної i методичної літератури; аналіз і узагальнення передового вітчизняного, зарубіжного та особистого педагогічного досвіду з проблеми дослідження.

\section{Результати та їх обговорення}

Ідея критичного мислення зародилася в США, починаючи свій розвиток від американських психологів XX ст. Вільяма Джеймса та Джона Дьюї. О. Бєлкіна (2000) визначає поняття критичне мислення, як здатність ставити під сумнів інформацію, що надходить людині, вміння оцінювати i осмислення про можливе прийняті рішення та вплив на них даної інформації. Інший автор О. Богданова (2006) вважає, що критичне мислення здобувачів освіти - це інтеграційна якість особистості, яка розвивається по мотиваційноціннісному, когнітивному i діяльнісного критерію i відкриває 
суб'єкту можливість виходу за межі заданих відносин і сформованих зв'язків.

О. Денисевич (2011) вважає, що критичне мислення є складною інтеграційною якістю особистості, сукупність мотиваційного, пізнавального, діяльнісного, рефлексивного компонентів, що забезпечують процеси його самопізнання, самоосвіти, самореалізації, також включає в себе вміння інтерпретації, аналізу, оцінки, висновки, пояснення, саморегуляції і навички проблемного мислення, діалогічного мислення, критичного аналізу.

На думку Д. Клустер, П. Фрейре, Дж. Дьюї, Р. Енніс, специфіка критичного мислення полягає у самостійності мислення (прагнення вирішувати складні завдання самому), допитливості (інтерес до всього невідомого, до того, що хочеться дізнатися), формулюванні проблеми і знаходженні виходу з ситуації, що склалася (аналітична компетенція, вміння знайти багато варіантів рішення і вихід з будьякої ситуації), прийняття обміркованих рішень (відповідальність за вибір свого рішення), вираження власної точки зору (наявність своєї точки зору і вміння іiї виказати і переконати інших у своїй правоті).

Вищезазначене дозволяє трактувати критичне мислення, як систему суджень, яка використовується для аналізу речей та подій 3 формулюванням обгрунтованих висновків і дозволяє робити учневі обгрунтовані судження та тлумачення, а також правильно застосовувати висновки до ситуацій та проблем. Загалом, критичне мислення відноситься до вищого рівня мислення. Критичне мислення - здатність людини ставити під сумнів отриману інформацію та власні переконання.

Один з активних прихильників цієї технології, професор Девід Кластер, чітко визначив ті процеси мислення, які не є критичним мисленням: просте запам'ятовування; розуміння думок інших, навіть найскладнішого та творчого чи інтуїтивного мислення, коли рішення приймається на основі просвітництва, а не раціонального, довгострокового мислення.

Доцільним є звернення до структури критичного мислення учнів. Узагальнюючи праці науковців, зазначимо, що критичне мислення учнів містить три компоненти:

- мотиваційний (в якому позитивна мотивація визначає успішність навчальної діяльності); 
- діяльнісний (пов'язаним зі здібностями до логічних умовиводів, встановлення асоціативних зв'язків і порівнянь);

- рефлексивно-оцінний (що включає в себе вміння школярів оцінювати і отримувану інформацію, і власну діяльність) (Корінько, 2010; Макаренко, 2007; Марченко, 2007).

У психолого-педагогічній літературі вчені намагалися виокремити етапи формування критичного мислення учнів (Максименко, 2000; Терно, 2012; Stancato, 2000):

1) перший і найважливіший етап - підготовка вчителя, здатного критично мислити та розвивати критичне мислення в учнів;

2) формування мотивів необхідності розвивати таку якість; та дій;

3) оволодіння учнями системою спеціальних логічних операцій

4) навчання учнів застосування знань цих операцій (тобто умінь) у навчальній діяльності та спілкуванні з однолітками та дорослими;

5) систематичний тренінг, коригування діяльності, відпрацювання окремих вправ щодо формування умінь критичного мислення.

На переконання вчених (Максименко, 2000; Терно, 2012; Stancato, 2000) учні мають пройти три основні стадії формування критичного мислення: стадія виклику, осмислення та роздумів. УТIM, з погляду, необхідна і четверта стадія - узагальнення і оцінка. Усі етапи не просто взаємопов'язані, а й взаємозалежні.

Згідно 3 перерахованими етапами формування критичного мислення учнів, нами була зроблена спроба розробити план проведення уроку, орієнтованого формувати критичне мислення за умов командної форми організації навчання.

Працюючи в команді, учні долають свої комплекси та поступово вчаться висловлювати свою думку, що дає навіть певний психотерапевтичний ефект. На наше переконання, спільна робота учнів у групі, при правильному її педагогічному керівництві, може сприяти формуванню соціально цінних якостей особистості учнів, моральних відносин між ними, навичок поведінки у колективі.

Навчання, орієнтоване на розвиток критичного мислення, сприяє становленню та розвитку моральних рис особистості - наполегливості, цілеспрямованості, пізнавальної активності та самостійності. Навчальна, освітня, трудова, комунікативна та інші 
види діяльності, стаючи змістом освіти, виходять за свої межі, щоб стати діяльністю моральної (Daud, 2004).

На основі вивчення етапів та способів формування критичного мислення учнів в умовах командної форми організації навчання спробуємо представити варіант моделі формування критичного мислення учнів. Розроблена нами модель пропонується як спільне керівництво для вчителів, метою якої $є$ їх підготовка та проведення уроків для учнів.

Основним завданням формування критичного мислення учнів розробленої нами моделі є:

- оволодіння учнями знаннями логічного, проблемного, творче мислення;

- навчання учнів основним логічним поняттям: рефлексія - заперечення - критика - критичність - самокритика - аргументація - доказ - спростування - оцінка - самооцінка -оцінне судження;

- формування в учнів умінь будувати критичні міркування у формі критичних міркувань, що має толерантний характер;

- навчання учнів виявленню логічних помилок критичної оцінки явища, поведінки.

В процесі розробки цієї моделі, нами були виявлені такі дидактичні умови формування критичного мислення:

- визначення умов розвитку критичного мислення, облік вікових та індивідуальних особливостей учасників команди, накопиченого досвіду учнів;

- визначення рівня сформованості критичного мислення членів команди;

- знайомство членів команди з логічною структурою та способами критичного ставлення до різних предметів;

- використання прийомів критичного мислення учителем під час презентації нового навчального матеріалу;

- виконання учасниками команди навчальних завдань, виконання яких потребує критичного мислення;

Слід зазначити, що цінним буде з огляду на досліджувану проблему використання наступних форм навчання при розвитку критичного мислення учнів:

1. Використання критичного мислення при груповому вирішенні завдань з урахуванням індивідуальних особливостей членів команди. 
2. Робота в групі при вирішенні проблемно-пізнавальних ситуацій учнів з відпрацювання умінь та навичок критичного мислення.

3. Групова робота учнів з урахуванням розподілу ролей у команді з виконання завдань, спрямованих на формування критичного мислення.

Огляд наукових досліджень доводить, що доцільним при розвитку критичного мислення учнів є реалізація таких методів навчання: створення мотивації в учнів до критичного осмислення змісту навчальних занять та прищеплення у них критичного ставлення до висловлювань та вчинків; визначення у структурі педагогічної технології рівнів сформованості критичного мислення «низького», «середнього», «високого»; використання технології проблемного навчання: методу проблемного викладу інформації, евристичного методу (метод виключення зайвих даних, і оцінка надійності джерела інформації), дослідницького методу, діалогічного, методів мотивації учнів щодо самостійного виконання логічних завдань 3 прийомами критичного мислення, тобто скрізь, де виникає запитання: «А якщо ...», «Що таке ...?»; використання логічного методу (аналіз, синтез, порівняння, узагальнення); використання методу рефлексивно-проблемного та критичного мислення під час вирішення групових завдань (Калашнікова, 2016; Макаренко, 2007; Матвієць, 2009).

\section{Висновки}

Отже, інноваційні процеси, що відбуваються в політичному, економічному, суспільному житті суспільства, також потребують змін у системі освіти. У сучасній освіті назріла необхідність підготовки майбутніх фахівців, здатних до розвитку, інновацій, до самостійного прийняття рішень, прояву гнучкості та ініціативи, тобто які мають спільні та професійні компетенції, необхідні для роботи в команді. Зміст навчання учнів у команді пов'язаний з набуттям знань, умінь та навичок, поряд 3 якими вони отримують навички колективної, групової, командної роботи.

Вміння критично мислити, будувати свою діяльність в умовах командної діяльності за умови сформованості мотиваційних установок для їх застосування у практичній діяльності можна назвати професійними компетенціями учнів. Використання форм організації навчання дозволяє учням засвоювати та формувати 
певні компетенції. Результати нашого дослідження показали, що ефективним засобом управління процесом формування критичного мислення, що відбувається в командах, є застосування прийомів та способів розв'язання проблемних завдань. Різні форми організації навчання застосовуються залежно від змісту навчання, дидактичних засобів, від індивідуальних особливостей рівня навчання учнів та рівня підготовки вчителів до розвитку критичного мислення учнів.

Перспективи подальших досліджень убачаємо в реалізації запропонованої моделі розвитку критичного мислення учнів в освітній процес закладу загальної середньої освіти.

\section{Література}

1. Бєлкіна О.В. Проблема формування критичного мислення в учнів початкових класів. Проблеми педагогічних технологій. Луцьк. 2000. №1. С. 50-57.

2. Богданова О. Використання методик розвитку критичного мислення на уроках історії. Історія України. 2006. № 9 (457). С. 6-12.

3. Денисевич О. О. Роль критичного мислення в освітній реформі вищої школи епохи інформаційного суспільства. Філософія. Культурологія. 2011. №1. С. 155-159.

4. Жерновникова О. А. Дидактична підготовка майбутніх учителів математики до проектування навчальної діяльності старшокласників: теоретичний та методичний аспекти : монографія. Харків : Видавець Іванченко І.С., 2015. 404 с.

5. Калашнікова Л. М., Жерновникова О. А. Педагогіка вищої школи в схемах і таблицях : навчальний посібник. Харків : ХНПУ імені Г. С. Сковороди, 2016. 0260 с.

6. Києнко-Романюк Л. А. Розвиток критичного мислення студентської молоді як загальнопедагогічна проблема: дис. ... кандидата пед. наук : 13.00.01 / Інститут вищої освіти НАПН України. Київ, 2007. 235 с.

7. Коваленко О.А., Жерновникова О.А.

Виховання інтелектуальної еліти нації: зарубіжний та вітчизняний досвід. Рідна школа. 2021. Вип. 3. С. 25-29.

8. Корінько Л. М. Роль критичного мислення у формуванні учнівських компетенцій. Харків : Вид. група «Основа», 2010. 95 с. 
9. Макаренко В. М. Урок математики в сучасних технологіях: теорія і практика. Розвиток критичного мислення. Модульне навчання : навч.-метод. посібник. Харків : Основа, 2007. 125 с.

10. Максименко С. Д. Мислення. Загальна психологія : підручник для студентів вищ. навч. закладів. Київ : Форум, 2000. С. 202-217.

11. Марченко О. Г. Формування критичного мислення школярів. Харків : Основа, 2007. 160 с.

12. Матвієць С. Розвиток критичного мислення в контексті компетентнісно орієнтованого навчання. Історія України. 2009. № 10 (602). C. 10-13.

13. Терно С.О. Методика розвитку критичного мислення школярів у процесі навчання історії: посібник для вчителя. Запоріжжя: Запорізький національний університет, 2012. 70 с.

14. Daud N. M. Developing Critical Thinking Skills in ComputerAided Extended Reading Classes. British Journal of Educational Technology. 2004. Vol. 35, №4. P. 477-488.

15. Stancato F. A. Tenure, Academic Freedom and the Teaching of Critical Thinking. College Student Journal. September, 2000. URL: http://findarticles.com/p/articles/mi_m0FCR/is_3_34/ai_66760558/.

\section{Остапенко А. В.}

\section{Критичне мислення учнів: суть, структура, умови розвитку}

\section{Анотація}

В статті проаналізовано та визначено суть поняття «критичне мислення», подано структуру критичного мислення. На основі розглянутого положення теорії розвитку критичного мислення за С. Терно та закономірностей, на яких грунтується ця методика, визначено процедури, які належать до операційного блоку критичного мислення. Суть поняття «критичне мислення учнів» трактується, як систему суджень, яка використовується для аналізу речей та подій 3 формулюванням обгрунтованих висновків і дозволяє робити учневі обгрунтовані судження та тлумачення, а також правильно застосовувати висновки до ситуацій та проблем. До особливостей розвитку критичного мис- 
лення учнів віднесено такі: закономірність динаміки, згідно 3 якою кількість усіх наступних змін залежить від кількості змін на попередньому етапі; закономірність розвитку особистості в освітньому процесі; закономірність управління освітнім процесом; закономірність стимулювання; закономірність єдності чуттєвого, логічного та практики в освітньому процесі; закономірність єдності зовнішньої (педагогічної) та внутрішньої (пізнавальної) діяльності; закономірність обумовленості освітнього процесу. Доведено, що структуру критичного мислення учнів становлять три компоненти: мотиваційний, діяльнісний, рефлексивно-оцінний. Автором розроблено модель розвитку критичного мислення учнів, завданнями якої $€$ : оволодіння учнями знаннями логічного, проблемного, творче мислення; навчання учнів основним логічним поняттям: рефлексія - заперечення - критика - критичність - самокритика - аргументація - доказ - спростування - оцінка - самооцінка -оцінне судження; формування в учнів умінь будувати критичні міркування; навчання учнів виявленню логічних помилок критичної оцінки явища, поведінки. Результати дослідження показали, що ефективним засобом управління процесом формування критичного мислення учнів $є$ застосування прийомів та способів розв'язання проблемних завдань, а різні форми та методи організації навчання застосовуються залежно від змісту навчання, дидактичних засобів, від індивідуальних особливостей рівня навчання учнів та рівня підготовки вчителів до розвитку критичного мислення учнів.

Ключові слова: учні, освітній процес, розвиток, критичне мислення, умови, структура, закономірності.

Остапенко А. В.

Критическое мышление учащихся: суть, структура, условия развития

Аннотация

В статье проанализировано и определено суть понятия «критическое мышление», представлено структуру критического мышления. На основе рассмотренного положения теории развития кри- 
тического мышления по С. Терно и закономерностям, на которых основывается эта методика, определены процедуры, относящиеся к операционному блоку критического мышления. Суть понятия «критическое мышление учащихся» трактуется как система суждений, которая используется для анализа вещей и событий с формулировкой обоснованных выводов и позволяет делать ученику обоснованные суждения и толкования, а также правильно применять выводы к ситуациям и проблемам. К особенностям развития критического мышления учащихся относятся следующие: закономерность динамики, согласно которой количество всех последующих изменений зависит от количества изменений на предыдущем этапе; закономерность развития личности в образовательном процессе; закономерность управления образовательным процессом; закономерность стимулирования; закономерность единства чувственного, логического и практики в образовательном процессе; закономерность единства внешней (педагогической) и внутренней (познавательной) деятельности; закономерность обусловленности образовательного процесса Доказано, что структуру критического мышления учащихся составляют три компонента: мотивационный, деятельностный, рефлексивно-оценочный. Автором разработана модель развития критического мышления учащихся, задачами которой являются: овладение учащимися знаниями логического, проблемного, творческого мышления. Результаты исследования показали, что эффективным средством управления процессом формирования критического мышления учащихся является применение приемов и способов решения проблемных задач, а различные формы и методы организации обучения применяются в зависимости от содержания обучения, дидактических средств, индивидуальных особенностей уровня обучения учащихся и уровня подготовки учителей к развитию критического мышления учащихся.

Ключевые слова: учащиеся, образовательный процесс, развитие, критическое мышление, условия, структура, закономерности. 